\title{
ВПЛИВ ІНФОРМАТИЗАЦІї НА МОЖЛИВІСТЬ ВІЛЬНОГО ДОСТУПУ ОСОБИ ДО ІНФОРМАЦЇ̈: ГЛОБАЛІЗАЦІЙНИЙ ВИМІР
}

\author{
КАПУШ Інна Ігорівна - здобувач кафедри адміністративного права і процесу, \\ фінансового права, інформаційного права Приватного вищого навчального \\ закладу «Львівський університет бізнесу та права»
}

DOI:10.32782/LAW.2019.3.31

УДК 342.15.47

\begin{abstract}
В статье рассмотренъ вопросъ инборматизации общества, въиступает совокупностью взаимосвязанных политических, соицально-якономических, научнълх и других бакторов, которые обеспечивают свободнъй доступ каждому илену общества к любъм источникам инбормации, кроме признаннъих на законодательном уровне тайной. Вълянено, что существенный прогресс в сфере инбормационных технологий стал основанием появления в научных и научно-популярных изданиях термина «информационное общество», в основу понимания которого положен знания. Указано, ито исторический процесс инборматизации общества точно описывается с помощью последовательности инбормачионных революицй, связанных с появлением новъгх для своего времени технологий. Информачионная револючия заключается в изменении способов и инструментов сбора, обработки, хранения и передачи инбормачии, что приводит к увеличению объема информации, доступной активной части населения. Таких револющий произошло шесть.

Ключевъе слова: инбормачионное общество, информатизаиия, информаиия, инбормационная револючия.
\end{abstract}

Постановка проблеми

Необхідність дослідження інформатизації та становлення інформаційного суспільства в нашій державі виявилася у тому, що за змістом людство підвищило інформацію в житті суспільства та окремої людини. Сьогодні ми активно переходимо від індустріального суспільства до інформаційного. Інформаційне суспільство - це така цивілізація, на якій головним пріоритетом $є$ інформація та знання. Інформатизація - це політика та процеси, створені на будівництві та розвитку телекомунікаційної інфраструктури, об'єднаної територіально-розподіленими інформаційними ресурсами.

Аналіз дослідження проблеми

Необхідно зауважити, що питання інформатизації стали предметом дослідження багатьох вчених, з-поміж яких праці I. Арістової, О. Баранова, К. Бєлякова, В. Гавловського, М. Гуцалюка, І. Жиляєва, С. Єсімова, Р. Калюжного, А. Новицького, В. Речицького, Р. Романова, А. Семенченко, О. Фролової, В. Цимбалюка, В. Хахановського, М. Швеця, А. Яременко та ін.

Мета статті полягає у дослідженні окремих питань щодо інформатизації та становлення інформаційного суспільства.

Виклад основного матеріалу

Історичний процес інформатизації суспільства точно описується за допомогою послідовності інформаційних революцій, пов'язаних з появою нових для свого часу технологій.

Інформаційна революція полягає у зміні способів та інструментів збору, обробки, зберігання і передачі інформації, що призводить до збільшення обсягу інформації, 


\section{Дискусії, обговорення, актуально}

доступній активній частині населення. Таких революцій шість.

Перша інформаційна революція полягає у появі мови і розбірливої людської мови.

Друга інформаційна революція пов'язана 3 винаходом письменності. Цей винахід дозволив не лише забезпечити збереження вже накопиченої людством суспільством інформацією, але й підвищити iii достовірність, створити умови для більш ширшого, аніж раніше, розповсюдження інформації.

Третя інформаційна революція породжена винаходом в XV столітті книгодрукарства, яке в багатьох випадках вважають однією $з$ перших інформаційних технологій. Поява i розвиток друкованих засобів масової інформації, таких як газети і журнали, стала результатом третьої інформаційної революції.

Четверта інформаційна революція розпочалась в XIX столітті. Тоді було винайдено такі засоби передачі і розповсюдження інформації як телеграф, телефон, радіо і телебачення.

П'ята інформаційна революція відбулась в середині XX століття, коли людство стало активно використовувати обчислювальну техніку. Застосування ЕВМ для обробки наукової інформації кардинально змінило можливість людини $з$ активної та ефективної обробки інформації. Вперше, за всю історію розвитку цивілізації, людина отримала високоефективний засіб для підвищення продуктивності інтелектуальної праці.

Сьогодні ми є свідками шостої інформаційної революції пов'язаної з появою глобальних телекомунікаційних комп'ютерних мереж і їх інтеграцією з технологіями мультимедіа та віртуальної реальності.

Шість інформаційних революцій змінили суспільство. Явним є розвиток і розповсюдження інформації та інформаційних технологій, що дозволяє говорити про наявність процесів інформатизації. Інформатизація надає вплив на всі сфери життєдіяльності суспільства, кардинально змінюе умови життя я діяльності людей, їх культуру, стереотип поведінки, образ мислення [1].

«Інформаційне суспільство - наявність такої соціальної структури, в якій висока пи- тома вага соціальних груп, так чи інакше зайнятих процесом виробництва, споживання і поширення інформації. У ньому домінуючими стають форми і види інформаційної праці, заснованої, як правило, на освітній діяльності, комп'ютерних технологіях та екранній культурі. В інформаційному суспільстві ключовим джерелом нововведень і основою соціальної організації стає знання» [2].

Становлення інформаційного суспільства зумовило потребу не тільки в нових технічних інформаційних системах, але і в розробці нових методів обробки, накопичення і поширення інформації. Все це дало потужний поштовх розвитку інформатики, інформаційної техніки (зокрема, появі мікропроцесорів, персональних комп'ютерів та ін.) і програмного забезпечення.

Отже, на початку третього тисячоліття склалися об'єктивні фактори переходу людства до нової сфери свого буття - інформаційної. По-перше, до цих факторів слід віднести те, що інформація знаходить нині статус найважливішого стратегічного ресурсу, що не тільки визначає розвиток економічної діяльності людини, але й впливає на політичну, правову, моральну сторони його життя. Надання інформації глобального статусу конституює іiї положення серед інших сфер продуктивної діяльності людини, дозволяючи вважати ії самоцінність достатньою підставою у становленні і розвитку матеріальної і духовної культури соціуму. У той же час реалізується одна з характеристик інформаційного суспільства: чисельність населення, зайнятого у виробництві, обробці і передачі інформації, починає перевищувати чисельність населення, зайнятого у сфері матеріального виробництва.

По-друге, з'являється універсальна можливість створення єдиного інформаційного простору, що забезпечує доступ кожного індивіда до інформаційних ресурсів. Але вже тут виникає глобальне протиріччя, що полягає у тому, що практично всі країни до середини XXI ст. повинні ввійти в нову стадію розвитку суспільства - інформаційну, хоча рівень їнього теперішнього розвитку, насамперед економічного, а також здатність захистити в міжнародному інформаційному 
просторі власний інтелектуальний потенціал дуже різні. Тому життєво необхідно розробляти і впроваджувати нові державні програми щодо захисту інформаційного простору з урахуванням економічних, політичних, правових, військових та інших інтересів держави, а також забезпечувати належний контроль у сфері інформатизації.

По-третє, науково-технічною основою формування нового суспільства виступають інформаційно-комунікаційні технології (ІКТ), цінність, обов'язковість і необхідність яких не підлягає сумніву. Тому становлення і розвиток інформаційно-комунікаційних технологій мають бути предметом пильної уваги з боку органів державного управління [3, c. 18-19].

Однією із найважливіших передумов побудови інформаційного суспільства в Україні $є$ створення сучасної інфраструктури інформатизації, основні елементи якої такі:

- телекомунікаційна складова;

- мережні інформаційні технології;

- сукупність інформаційних ресурсів;

- засоби обчислювальної техніки, мережне обладнання та програмне забезпечення;

- прикладні інформаційні технології;

- система забезпечення інформаційної безпеки;

- сукупність кваліфікованих кадрів і система їх підготовки та перепідготовки;

- система науково-методичного забезпечення;

- система нормативно-правового забезпечення;

- система стандартизації та сертифікації;

- система класифікації та кодування інформації;

- система виробництва та впровадження компонентів інформаційної інфраструктури [4].

За допомогою становлення в Україні інформаційного суспільства, очікується таке:

- здатність забезпечення широкого набору телекомунікаційних послуг;

- розширення ринків для постачальників комп'ютерного обладнання та програмного забезпечення;

- суттєве підвищення якості життя громадян, реальне надання їм більш широкого спектра послуг;
- значне зростання попиту інтелектуального та творчого потенціалу громадян для забезпечення збільшення обсягів нових продуктів та послуг;

- принципово нові можливості для поширення інформації щодо наукових та культурних надбань і всередині країни, і за іiі межами;

- дійсна демократизація влади усіх рівнів, прозорість їі дій, забезпечення ï повної інформаційної взаємодії із громадянами;

- поява більш рівних можливостей для усіх громадян, ведення малого і середнього підприємництва завдяки забезпеченню вільного доступу до інформації з будь-яких джерел, до освітянських і культурних програм.

3 огляду на це, створення інформаційного суспільства, підготовка української спільноти до його сприймання є вкрай важливими державними завданнями, що має здійснюватися шляхом повсюдної інформатизації та запровадження чіткого адміністративно-правового забезпечення контролю у цій сфері.

Законодавче забезпечення розвитку інформаційного суспільства передбачає створення цілісної системи законодавства, гармонізованої з нормами міжнародного права 3 питань розвитку інформаційного суспільства, зокрема здійснення кодифікації інформаційного законодавства [5].

При створенні інформаційного законодавства слід керуватися загальними принципами Конституції України, а також базуватися на принципах свободи створення, отримання, використання та розповсюдження інформації; об'єктивності, достовірності, повноти і точності інформації; гармонізації інтересів людини, суспільства та держави в інформаційній діяльності; обов'язковості публікації інформації, яка має важливе суспільне значення; обмеження доступу до інформації виключно на підставі закону; мінімізації негативного інформаційного впливу та негативних наслідків функціонування IКТ; недопущення незаконного розповсюдження, використання і порушення цілісності інформації; гармонізації інформаційного законодавства та всієї системи вітчизняного законодавства [5]. 


\section{Дискусії, обговорення, актуально}

\section{АНОТАЦІЯ}

у статті розглянуто питання інборматизаиї суспільства, що виступає сукупністю взаємопов'язаних політичних, сочіально-економічних, наукових та інших чинників, які забезпечують вільний доступ кожному илену суспільства до будь-яких джерел інбормаиій, окрім визнаних на законодавчому рівні таємницею. З'ясовано, щь суттєвий прогрес у сфері інбормаційних технологій став підставою появи в наукових і науково-популярних виданнях терміна «інбормаиійне суспільство», в основу розуміння якого покладено знання. Вказано, що історичний процес інборматизациї суспільства точно описується за допомогою послідовності інформаційних револючій, пов'язаних 3 появою нових для свого часу технологій. Інформаційна револючія полягає у зміні способів та інструментів збору, обробки, зберігання $i$ передачі інбормаиї, що призводить до збільшення обсягу інбормациї, доступній активній частині населення. Таких революиій відбулося uicms.

Ключові слова: інформачійне суспільство, інборматизачія, інбормачія, інбормачійна револючія.

\section{Висновки}

Отже, сучасне поширення інформаційнокомп'ютерних технологій та мереж, які активно сприяють нарощуванню інформаційних ресурсів у різних за призначенням базах даних, викликане економічною потребою в отриманні переваг у конкурентній боротьбі. За умов глобалізації інформаційних процесів, що супроводжуються різними видами злочинів проти особи, суспільства або держави, країни багато втрачають, якщо діють розрізнено, не дотримуючись загальних принципів та правил, визначених міжнародними стандартами. Узгодженість правових норм країн та спільнот, тобто адаптація національних законодавств, за умов необхідності упорядкування інформаційних відносин, зокрема в електронно-інформаційному середовищі, є досить актуальною та складною проблемою.
The article deals with the issues of informatization of a society, which is a set of interrelated political, socio-economic, scientific and other factors that provide free access to any member of the society to any sources of information, except for the secrecy recognized at the legislative level. It has been found that the significant progress in the field of information technology has become the basis for the emergence of the term "information society" in scientific and popular science editions, which is based on understanding. It is stated that the historical process of informatization of a society is accurately described with the help of a sequence of information revolutions connected with the advent of new technologies of its time. The information revolution is about changing the ways and tools of gathering, processing, storing and transmitting information, leading to an increase in the amount of information available to the active population. There were six such revolutions.

Keywords: information society, informatization, information, information revolution.

\section{Лiтература}

1. Єсімов С.С. Формування єдиного інформаційного простору в діяльності державних органів України. Вісник Начіонального університету «Аьвівська політехніка». Серія. Юридичні науки. 2015. № 813. С. 48-53.

2. Разуваев В.Э. Информатизация в юриспруденции: правовой режим информационных ресурсов. URL: [www.tarasei.narod. rU/read/st2003.2.htm].

3. Мороз Н.С. Адміністративно-правове забезпечення державного контролю у сфері інформатизації: дис. канд. юрид. наук; спец. 12.00.07. К. 2016. С. 18-19.

4. Звіт про роботу Національної комісії що здійснює державне регулювання у сфері зв'язку та інформатизації за 2014 рік. К.: НКДРЗІ, 24.03.2015. 78 с. URL: [http:// nkrzi.gov.ua/images/upload/142/5369/r165 dod 2015-03-24.pdf].

5. Мороз Н. С. Поняття та сутність контролю у сфері інформатизації. Вісник $\mathrm{Ha}$ иіонального університету «Аввівська політехніка». Серія: Юридичні науки. 2016. № 3. C. $137-141$. 